\title{
The Environmentally Conscious Consumption in Morocco: Myth or Reality
}

\author{
Dalal Tarfaoui ${ }^{1}$ \\ Salah Zkim² \\ Université Hassan 1er Settat, Morocco \\ 1 tarfaoui_dalal@hotmail.fr; 2 salah_Zkim@gmail.com
}

\section{Doi:10.5901/ajis.2015.v4n3s1p34}

\section{Abstract}

\begin{abstract}
Morocco has adopted significant measures to enhance the social equity and people's well-being. Large projects have been launched to reduce the issue of carbon emissions and preserve the environment from pollution and deterioration. Green consumption has also been considered as a major pillar of sustainable development, as it contributes to the safeguard of the environment through friendly behavior. This article examines the environmentally conscious consumption in Morocco through the Information Display Board (IDB) method. The research aims at finding whether green buying belongs to the Moroccan lifestyle given the appropriate conditions, or only a myth that has been brought up to complete the whole picture of Moroccan environmentalism. The IDB method allows the understanding of the way in which someone (the decision maker) gathers information and uses it in his/her decision process. Through the IDB method, a so-called realistic experimental situation has been created to track Moroccans' purchase decisions regarding an eco-product versus a non-eco product. The present article has uncovered the lack of concern Moroccans have towards the environment, the products' price is ultimately the deciding factor. The implications of the results of the environmentally conscious consumption in Morocco are discussed at the end of the paper.
\end{abstract}

Keywords: Environmentally conscious consumption, Information Display Board method, Moroccans green consumption.

\section{Introduction}

Waste generated by human consumerism is increasing drastically; the throw-away items have appeared with the industrial revolution (Muldoon, 2006) and have been easily integrated in many peoples' lifestyles. The time pressure and other factors made people purchase new products rather than re-use (Geyer \& Jackson, 2004) or make their own. Some people become aware of the dire situation, got involved in some type of environmental activities and have adopted some sort of responsible behavior. Environmentally responsible behavior has always been considered as a cornerstone in assuring better environment preservation. Responsible behavior is described as activities that contribute to the conservation of the environment (Axelrod \& Lehman, 1993), and it includes recycling, energy conservation, political activism, and so forth (Kaiser \& Fuhrer, 2003). The present article sheds some light on environmentally conscious consumption within the Moroccan context. Moroccan government has adopted significant projects such as water security, pollution, and desertification (Tarfaoui \& Zkim, 2015), but few have realized the importance of the role played by the behavioral patterns on environmental safeguarding. Many researchers have stated that technology isn't the only way to preserve the environment (Ajzen \& Madden, 1986), and through adopting a responsible lifestyle and controlling the consumption choices, the individual can foster a less polluted environment (Kaiser \& Fuhrer, 2003).

\section{Theoretical Framework}

Environmentally conscious consumerism is "the purchasing and non-purchasing decisions based at least partly on environment or social criteria" (Peattie \& Ratnayaka, 1992). It has been found to be related to many predictors; environmental knowledge (Ajzen \& Madden, 1986), that's considered as an interesting factor to promote ecological behavior. Some studies have stated that environmental knowledge is an ingredient to explain, only partially, the responsible behavior as other behavior-proximal mediators are required to better outline the responsible environmental behavior (Oskamp et al., 1991).

Motivation is also considered as an internal factor around which behavior is shaped. The motive is divided into two types: extrinsic motives and intrinsic motives (Kollmuss \& Agyeman, 2002). Motivation is described as the drive that 
exists either within the individual him/herself, or from outside that makes a person behave accordingly. Social and cultural factors (Boehmer-Christiansen, Skea, \& others, 1991) are not to be underestimated in explaining ecological behavior and green purchasing. It has been hypothesized that cultures in highly populated and small countries seem to be more resource conscientious than people in large countries (Kollmuss \& Agyeman, 2002).

Perceived consumer effectiveness (PCE) which is similar to self-efficacy (Bandura, 1986), has also been proven to be linked to green purchasing (Kim \& Choi, 2005). PCE is someone's perception about his/her ability to bring change by his/her action (Berger \& Corbin, 1992), as hypothesized(Kim \& Choi, 2005), "PCE directly and positively relates to green purchase behavior. People who have higher PCE are more likely to engage in environmental consumption than are those with lower PCE.

As to the environmental attitude, it is considered as a predictor by some studies (Fishbein \& Ajzen, 1975), but in most cases, has been the subject of an interesting debate (Mainieri, Barnett, Valdero, Unipan, \& Oskamp, 1997). Attitude has been defined as "an enduring set of beliefs, about an object, that predispose people to behave in particular ways toward the object" (Weigel, 1983). However, in environmental attitude-behavior relationship, the question highlighted is whether environmental attitude predicts effectively the ecological behavior (Mainieri et al., 1997). Environmental consumerism studies have revealed a lag between environmental attitude and ecological behavior. This attitude-behavior gap has been mainly explained by the effect of other external variables and the inconsistencies in the ecological attitudebehavior measurements (Mainieri et al., 1997).

In Chase's study (1991), most of the participants have reported to be ecological and have undertaken some environmental activities. However, they seem skeptical regarding the environmental claims. They stated not to be confident about the advertisers' information about the real impact of the products. The apprehension might be justified by the widespread deceptive spin which is known as "green washing". Some of the companies that are conscious of the increasing concern that their customers have towards the environment have started to 'green up' their products. This 'disguised attempts' (Brenkert et al., 1998) aim more often, marketing ploys to convince consumers to purchase more. Nebulous descriptions are used like 'low carbon' or 'natural' are most of the case misleading as they are unsubstantiated. For this reason, people who have reported to be ecological and have rarely or haven't at all engaged in green purchasing have stated to be lacking trust towards these "green labeled" products. The Consumers' perception, that a company is socially and ecologically oriented, is associated with a higher level of trust in that company and its products (Misani \& Pivato, n.d.). Therefore, trust is crucial for understanding business relationships when one who trusts is in a vulnerable (high risk) position (Vlachos, Tsamakos, Vrechopoulos, \& Avramidis, 2008). If consumers think that the claim is not reliable, they are likely to disregard all environmental claims, thereby avoiding any product that may in fact be better for the environment (Mayer et al., 1995).

Responsible consumption, ecological behavior, and green purchasing are all controversial concepts to talk about in Morocco. According to Tarfaoui \& Zkim (2015), Moroccans purchasing behaviors seem to be affected by economic factors. They have pointed out that eco-products are usually more expensive than similar non eco-products. They are more enticed by the financial factor when it comes to the act of purchase (Aomari, n.d.), rather than any ecological related characteristic. This behavior is common in developing countries, environment matters seem to be people's last concern (Kollmuss \& Agyeman, 2002) as there are other problems that distress their wellbeing in the short term (e.g. hunger, poverty and so forth). Moroccan society doesn't praise a friendly behavior toward the environment (Tarfaoui and Zkim, 2015), so this makes a green purchasing unlikely to happen.

\section{The Aim of the Study}

Many studies have been conducted to research the predictors of ecological behavior and green purchasing (Gamba \& Oskamp, 1994; Vining \& Ebreo, 1990; Werner \& Makela, 1998). The list of theses predictors, or antecedents as it is called by other researchers (Kim \& Choi, 2005), are plentiful, ranging from internal variables (e.g. motivation, attitude and awareness) to external variables (e.g. economic, institutional and social) (Kollmuss \& Agyeman, 2002).

The chief task in the present article is to understand whether the green purchasing belongs to Moroccan reality or it is still a theoretical concept that is far from proving its existence among the Moroccan mindset.

The increasing environmental speeches, studies and researches haven't revealed any disclosure about Moroccan human ecological behavior, yet very rare and practically inexistent studies have investigated the Moroccan green purchasing. The following questions come to surface to modestly enlighten the extent to which Moroccans contribute to the wellbeing of the environment while purchasing.

Do Moroccans take into consideration the environment before purchasing their products? 
What is the type of criteria in order of importance, that the Moroccan consumer evaluates in his/her decision making process?

Do ecological attributes belong to the selection list used by Moroccans while purchasing?

\section{Method}

Ecological researchers have stated that measuring ecological behavior across various fields has been troublesome. A tracking method called, Information Display Board (IDB) (Jacoby, Chestnut, \& Fisher, 1978), has been used in this study to track Moroccans' selection process to make a final purchasing decision. The objective of this method is to come near to a real life condition when making a decision. First of all, it's the only method that allows a tracking selection process and examines how consumers use the available information to make a purchasing decision. The second advantage of this method is that, it's not affected by social desirability, that in most ecological behavior measurements induce an unintentional bias and less reliable data.

An introduction of the study is provided to thirty nine participants. A scenario is presented to the participants where they are asked to choose a product/alternative from the matrix presented. At each intersection between column and row, there's information that can be checked. The matrix is presented using an array of face down paper cards. The participants are asked to consult the information that seems to be important. Each of the participants flipped the card to consult the information then puts it back face down. The participants viewed as many cards as they wanted until they made a final decision. The Matrix was completed by an open question about the green purchasing and the core factors that can lead to adopt such purchasing. Secondary sources information have been used to choose the product category and the attributes. The choice of attributes (eco-product/non eco-product) was refined based on consumer magazines, websites and forums. A double entry table (matrix) was presented to the subjects of the experiment. In rows; there are different products, and in the columns, attributes of those products. The product category is "detergent", and in the columns; product ingredients (contains synthetic dyes or not), price, package (recyclable or reusable), cleaning power, company names, country of origin, and the ecological safety. The presentation of the matrix is most often in symmetrical form. Thus we have presented as many products' alternatives as attributes, seven in total.

A pre-test is performed to acquaint the participants to the method before the final implementation.

The results of the experiment are measured by:

- The amount of information used (the number of turned cards), expressed as a percentage of the total number of cards.

- The identity of information (the nature of information), by calculating the average on each attribute.

- The acquisition method: alternatives strategy; going along the lines (columns) when consulting the card or attribute strategy; going along the attributes (rows) when turning the cards.

- The processing sequence (the order of cards used/turned).

The table is presented as shown below:

\begin{tabular}{|l|c|c|c|c|c|c|c|}
\hline & $\begin{array}{c}\text { Product ingredient } \\
\text { (contains synthetic dyes or not) }\end{array}$ & $\begin{array}{c}\text { Package (recyclable } \\
\text { or reusable) }\end{array}$ & $\begin{array}{c}\text { Cleaning } \\
\text { power }\end{array}$ & $\begin{array}{c}\text { Company } \\
\text { names }\end{array}$ & $\begin{array}{c}\text { Country of } \\
\text { origin }\end{array}$ & $\begin{array}{c}\text { Ecological } \\
\text { safety }\end{array}$ & Price \\
\hline Product 1 & $?$ & $?$ & $?$ & $?$ & $?$ & $?$ & $?$ \\
\hline Product 2 & $?$ & $?$ & $?$ & $?$ & $?$ & $?$ & $?$ \\
\hline Product 3 & $?$ & $?$ & $?$ & $?$ & $?$ & $?$ & $?$ \\
\hline Product 4 & $?$ & $?$ & $?$ & $?$ & $?$ & $?$ & $?$ \\
\hline Product 5 & $?$ & $?$ & $?$ & $?$ & $?$ & $?$ & $?$ \\
\hline Product 6 & $?$ & $?$ & $?$ & $?$ & $?$ & $?$ & $?$ \\
\hline Product 7 & $?$ & $?$ & $?$ & $?$ & $?$ & $?$ & $?$ \\
\hline
\end{tabular}

Figure 1: Information Display Board as presented to the participant

\section{Results \& Discussion}

In this realistic experimental situation, Moroccans have assessed, in this order of importance, the following criteria: price, cleaning power, and companies name to reach their final purchase decision. The attributes that constitute the ecological features of a product (an eco-product): packaging, ingredients, and the ecological safety have been the least and the last important factors listed in the Moroccans' decision making process. Even if the concept of responsible buying is gradually 
taking hold in Morocco, the results seem debatable. Despite the great number of consumers reporting their ecological behavior in the open question asked, only a few people have chosen "ecological" products or have engaged in "green purchasing". The lack of trust toward green companies and products has been observed in most of the participants. Moroccans have shown their lack of enthusiasm towards green labels (ecological features) and stated that those features are only used as marketing technics in most cases. As expounded earlier, there are companies that 'green up' their products to fool the consumer. The price seems the ultimate motivator for Moroccans, as per Mandese (1991), even with green consumers; financial barriers are still an issue as they are extremely price-sensitive while buying ecological products.

A study of Arnot, Boxal, \& Cash (2006), has examined the price sensitivity comparing the response of fair trade coffee consumers and non-fair trade brewed coffee consumers to price variation. The study is undertaken in a real context market. The results showed that fair trade coffee consumers are much less price sensitive than those of other coffee product. The study disclosed that true ethical consumer don't care about the price as long as the product features carries the planet welfare in mind. However, the study was held in a first world country, where people's wellbeing is assured at high standards of living which affords those people the luxury to care about the safety of the environment as well.

The present article has uncovered the lack of concern Moroccans have towards the environment. The reality of environmental consumerism in Morocco is overshadowed by the high importance of the pricing factor. Consumerism reality in developing country can only reveal pseudo-ethical consumers, who care about the environment, would like to act to preserve the nature, but get limited by some variables (financial barriers mostly) that prevent the good intention from translating into action.

\section{Research Limitations}

As per any research, this study has its limitations. The limitation is particularly regarding the implementation of the IDB method. The automation of procedures is considered better than the original IDB method, because the experiment is identical for all the participations, and the experiment can be conducted by several people at the same time, and getting instant results. The automation of the method is a time and energy saver, it's more reliable than a manual data entry and the tedious observation of each subject (Lallement, 2008). However, a search for a ready-to-use software to implement the IDB method has been unsuccessful (Lallement, 2008). In the USA, there are some programs that can perform the information processing, called 'Deal Search' (Schurr \& Brucks, 1991), and can certainly be used for IDB method but the cost is very expensive and advanced knowledge in computing programming is required to use it. Thus, we used the original method, employing paper cards and two observers to observe and take note in the experiment process.

There is another limit to this article; a preliminary study has not been conducted in choosing the attributes of the product or the product category. Using only secondary sources information to refine the list of attributes used in the research hasn't been as interesting as would have been the usage of primary data.

\section{Future Research and Conclusion}

Trust helps people make the 'leap of faith' into action because it embodies feelings of security about the object of trust (Harrison McKnight, Choudhury, \& Kacmar, 2002), such that one can move forward without fear in spite of the risks or uncertainties in a situation (Holmes, 1991). Moreover, it allows consumers to overcome perceptions of risk and uncertainly and to engage in specific behaviors (Mayer, Davis, \& Schoorman, 1995). Besides all that, the literature assumes that trust when present, is translated into a consumer's intention to act. For that reason, we believe that trust is a relevant variable to investigate and measure its effect on explaining the Moroccan green purchasing and ecological attitude behavior Gap. Adam Smith (1997) observed notable differences across nations in the 'probity' and 'punctuality' of their populations (Zak \& Knack, 2001). We take it as granted that populations of some countries are more trusting than others. According to Bjørnskov (2006), social polarization in the form of income inequality and ethnic diversity reduces trust, also protestantism and being ruled by a monarchy increases trust, while post-communist societies are less trusting than others. Therefore, we can hypothesize that more trusting Moroccan consumers are more willing to engage in green purchasing that less trusting ones. 


\section{References}

Ajzen, I., \& Madden, T. J. (1986). Prediction of goal-directed behavior: Attitudes, intentions, and perceived behavioral control. Journal of Experimental Social Psychology, 22(5), 453-474.

Aomari, A. (n.d.). The Responsible Consumption: Factor of the Development of Environmental Responsibility in Morocco. Retrieved from http://www.joebm.com/papers/128-L20003.pdf

Arnot, C., Boxall, P. C., \& Cash, S. B. (2006). Do ethical consumers care about price? A revealed preference analysis of fair trade coffee purchases. Canadian Journal of Agricultural Economics/Revue Canadienne D'agroeconomie, 54(4), 555-565.

Axelrod, L. J., \& Lehman, D. R. (1993). Responding to environmental concerns: What factors guide individual action? Journal of Environmental Psychology, 13(2), 149-159.

Bandura, A. (1986). Social foundations of thought and action: A social cognitive theory. Prentice-Hall, Inc. Retrieved from http://psycnet.apa.org/psycinfo/1985-98423-000/

Berger, I. E., \& Corbin, R. M. (1992). Perceived consumer effectiveness and faith in others as moderators of environmentally responsible behaviors. Journal of Public Policy \& Marketing, 79-89.

Bjørnskov, C. (2006). The multiple facets of social capital. European Journal of Political Economy, 22(1), 22-40.

Boehmer-Christiansen, S., Skea, J., \& others. (1991). Acid politics: environmental and energy policies in Britain and Germany. Belhaven Press. Retrieved from http://www.cabdirect.org/abstracts/19910649901.html

Brenkert, G. G., Brown, D. A., Buchholz, R. A., Daly, H. E., Dodd, R., Freeman, R. E., ... others. (1998). The Business of Consumption: Environmental Ethics and the Global Economy. Retrieved from http://philpapers.org/rec/BRETBO-7

Fishbein, M., \& Ajzen, I. (1975). Belief, attitude, intention and behavior: An introduction to theory and research. Retrieved from http://trid.trb.org/view.aspx?id=1150648

Gamba, R. J., \& Oskamp, S. (1994). Factors influencing community residents' participation in Comingled curbside recycling programs. Environment \& Behavior, 26, 587-612.

Geyer, R., \& Jackson, T. (2004). Supply loops and their constraints: the industrial ecology of recycling and reuse. California Management Review, 46(2), 55-73.

Harrison McKnight, D., Choudhury, V., \& Kacmar, C. (2002). The impact of initial consumer trust on intentions to transact with a web site: a trust building model. The Journal of Strategic Information Systems, 11(3-4), 297-323. http://doi.org/10.1016/S09638687(02)00020-3

Holmes, J. G. (1991). Trust and the appraisal process in close relationships.

Jacoby, J., Chestnut, R. W., \& Fisher, W. A. (1978). A behavioral process approach to information acquisition in nondurable purchasing. Journal of Marketing Research, 532-544.

Kaiser, F. G., \& Fuhrer, U. (2003). Ecological behavior's dependency on different forms of knowledge. Applied Psychology, 52(4), 598613.

Kim, Y., \& Choi, S. M. (2005). Antecedents of green purchase behavior: An examination of collectivism, environmental concern, and PCE. Advances in Consumer Research, 32, 592.

Kollmuss, A., \& Agyeman, J. (2002). Mind the gap: why do people act environmentally and what are the barriers to pro-environmental behavior? Environmental Education Research, 8(3), 239-260.

Lallement, J. (2008). Les effets de la pression temporelle sur le traitement des informations et le comportement d'achat. Tours. Retrieved from http://www.theses.fr/2008TOUR1003

Mainieri, T., Barnett, E. G., Valdero, T. R., Unipan, J. B., \& Oskamp, S. (1997). Green buying: The influence of environmental concern on consumer behavior. The Journal of Social Psychology, 137(2), 189-204.

Mandese, J. (1991). New study finds green confusion. Advertising Age, 62(45), 1-56.

Mayer, R. C., Davis, J. H., \& Schoorman, F. D. (1995). An integrative model of organizational trust. Academy of Management Review, 20(3), 709-734.

Misani, N., \& Pivato, S. (n.d.). The impact of corporate social responsibility on consumer trust : the case of organic food. Business Ethics A European Review, 17(1), 3-14.

Muldoon, A. (2006). Where the green is: Examining the paradox of environmentally conscious consumption. Electronic Green Journal, 1(23). Retrieved from http://escholarship.org/uclitem/00t326gx.pdf

Oskamp, S., Harrington, M. J., Edwards, T. C., Sherwood, D. L., Okuda, S. M., \& Swanson, D. C. (1991). Factors Influencing Household Recycling Behavior. Environment and Behavior, 23(4), 494-519. http://doi.org/10.1177/0013916591234005

Peattie, K., \& Ratnayaka, M. (1992). Responding to the green movement. Industrial Marketing Management, 21(2), $103-110$.

Schurr, P. H., \& Brucks, M. (1991). Deal Search: An Approach for Computer-Controlled Information Processing Experiments Involving Bargainable Attributes. Advances in Consumer Research, 18(1). Retrieved from http://search.ebscohost.com/login.aspx?direct =true \&profile=ehost $\&$ scope=site \&authtype=crawler \&jrnl=00989258\&AN=6522251\&h=ROc2jeKJGDolzlQeESu0mpCsqlT6wg8VL DY\%2BI7LaZ2NOwOmlZ\%2Fih7jSd6XjYh\%2FWvhEB2e7lym100aAP\%2BCgmHGw\%3D\%3D\&crl=c

Tarfaoui, D., \& Zkim, S. (2015). Moroccan Human Ecological Behavior: Grounded Theory Approach. In International Interdisciplinary Business-Economics Advancement Conference (p. 375). Retrieved from http://lasvegasmay2015.iibaconference.org/wpcontent/uploads/4th_IIBA_Conference_Proceedings_Las_Vegas_May_2015.pdf\#page=384

Vining, J., \& Ebreo, A. (1990). What makes a recycler? A comparison of recyclers and nonrecyclers. Environment \& Behavior, 22, 55-73. Vlachos, P. A., Tsamakos, A., Vrechopoulos, A. P., \& Avramidis, P. K. (2008). Corporate social responsibility: attributions, loyalty, and 
the mediating role of trust. Journal of the Academy of Marketing Science, 37(2), 170-180. http://doi.org/10.1007/s11747-0080117-x

Weigel, R. H. (1983). Environmental attitudes and the prediction of behavior. Environmental Psychology: Directions and Perspectives, 257-287.

Werner, C. M., \& Makela, E. (1998). Motivations and behaviors that support recycling. Journal of Environmental Psychology, 18, 373386.

Zak, P. J., \& Knack, S. (2001). Trust and Growth. The Economic Journal, 111(470), 295-321. http://doi.org/10.1111/1468-0297.00609. 